\title{
A Conversation with Warwick Soden (Principal Registrar and Chief Executive Officer, Federal Court of Australia)
}

Interviewed by Kim Rubenstein and Ann Genovese

On 28 January 2016, Kim Rubenstein and Ann Genovese interviewed Warwick Soden for the Court as Archive Project, at the Principal Registry in Sydney. Mr Soden is the Chief Executive Officer of the Federal Court of Australia, a position he has held since 1994. In the full interview, we discuss the status and management of court records over time, as well as Warwick's experiences in undertaking his duties in Court Administration, over the period of his career.

The Federal Court archivist, Lyn Nasir, was also present.

$1 \quad$ Please cite as Warwick Soden and Lyn Nasir, interview Kim Rubenstein and Ann Genovese in Ann Genovese, Trish Luker and Kim Rubenstein (eds), The Court as Archive (ANU Press, 2019). 
Included below is a selection from the interview concentrating on aspects relevant to this collection. Further publications from the interview are planned, given that the interview with Warwick Soden is a rare example of an oral history undertaken with a key administrative office holder of the Federal Court. ${ }^{2}$

The interview was conducted on the eve of the court's $40^{\text {th }}$ anniversary as a national institution and should be read as capturing the respective participants' thinking at that time. Indeed, some of the issues discussed have since progressed, but its essence and content maintain its value on a number of levels relevant to this research.

Kim Rubenstein (KR): Warwick, we would like to start by asking you when you joined the Federal Court, and what you had been doing before, to understand the relationship between your expertise and coming to the court.

Warwick Soden (WS): Well, for about eight years prior to coming to this court, I was the Chief Executive and Principal Registrar of the Supreme Court of New South Wales. Now, that is a long time ago.

KR: Yes, when was that?

WS: I went to the Supreme Court of New South Wales in 1987—early 30 s at that time. I thought I was old at that time!

[Laughter]

In 1972, I think I was about 18 and a half, 19, I started working in the courts in New South Wales_primarily what were then called the Courts of Petty Sessions_-and did my law degree part-time.

Ann Genovese (AG): At the University of New South Wales?

WS: No. I ended up doing it remotely, through Macquarie Law School because I was in the country and I needed to do all my study externally. It took me about four or five years to do it.

2 The Federal Court has undertaken oral histories with former Federal Court judges and Federal Court judges have also been interviewed as part of the ARC Linkage Project, The Trailblazing Women and the Law Project (ARC Linkage LP120200367). See Australian National University and University of Melbourne, 'The Trailblazing Women and the Law Project' (30 November 2016) The Trailblazing Women and the Law Project <http://www.tbwl.esrc.unimelb.edu.au>. 
AG: Would it be fair to say that, for you, the commitments and demands of the job were supplemented by your degree, rather than the other way around? Because for many people, they're doing the degree to get the job, and you've already ...

WS: I was working in the courts, and in that whole scheme, they had what were called in those days, exam barriers. So as you progressed through university, you were able to be promoted because of your partial legal qualifications, as long as you had some managerial acumen. Which, luckily, I did. So I was fortunate in being quite young, finishing my law, and there weren't other people who had done their law in the system who were competing for a job. So I ended up being in some quite senior positions in the New South Wales court system prior to going into the Supreme Court. I was what was called, I think, the Registrar or the Clerk of the court, or whatever it was called in those days for Wollongong. So that included being ... the Coroner for the City of Wollongong. So I did all the coronial enquiries from things like deaths in the steel works and mine collapses and all that sort of stuff.

AG: And this is when you were still very young.

WS: I was early 30s. At that time, there were a lot of industrial accidents occurring and the Supreme Court had an industrial accident jurisdiction with juries. That's all gone now. So I spent some time in the Supreme Court, learning Supreme Court practice and procedure with people there, and set up the Supreme Court registry in Wollongong. So I got involved in some of the policies and procedures in delay reduction and case management, and ended up being asked to be in the Supreme Court [in Sydney]. For a while, acting, and then was appointed.

AG: What year was that?

WS: That was '88: ' 87 to '88 from memory. So one of the things that was important, as an issue for me in the Supreme Court, was not only the delay and reduction initiatives, and all the case management work that we did, but there was also a whole lot of records work that was being done, for example, a whole lot of microfilming of old probate records. One of the things I found amazing at that time was the indexes to the probates-big index books — were in a complete state of disrepair and just rotting away.

AG: Where were they all housed? 
WS: In the dungeon of this building [No. 1 Queen's Square, Sydney]. I went and got one, which was just a sample, and it was almost unusable. It went back to the days of things like the will of James Ruse, you know, which is from the time of the early settlers, and these things were just going to be destroyed. So I had copies done that were preservable and all that sort of thing. So I don't think that was the start of my interest in records or archives but it was an issue at that stage. It was a no-brainer to me at the time that some things must be preserved that weren't being preserved. That led to a lot of issues about court records, what comprises the court records, et cetera. Although I was in the Supreme Court for, I think, eight years, most of the time with Murray Gleeson subsequently as Chief Justice, the focus of my work then was case management and delay reduction. We did turn it around substantially to be much better than it had been. So I didn't focus as much as I could have on records issues. But we did touch upon, even in those early days, the issue of what comprised the court record.

I can remember it was Gleeson who made it indelibly clear in my mind that the court record doesn't comprise anything more than-this is the official court record of a superior court—who sued what for whom and what was the result?

AG: So where were all the records kept?

WS: Most of it was here. There were some offsite archives. But I'm not sure what was offsite and what was here. I know probate was here. I think most of the probate work was here, or probate records were here.

AG: So the relationship between courts and departments or administering agencies is really fascinating to us. As we were saying before this interview started, our archival searches at NAA [National Archives of Australia] show that in the early years of the Federal Court, the court was trying to manoeuvre or navigate its relationship with Attorney-General's Department, when that's in Canberra and you're setting up state-based registries, it was quite a distinct theme or narrative.

WS: Well, can I say, by 1994 at the time when self-administration was under consideration, there was quite a large movement in [the] Australasian Institute of Judicial Administration by a number of judges and others on the subject of the governance of courts. The Australian got involved. There were seminars and conferences on the subject of the governance of courts because a lot of courts were having problems with resource allocation and being able to control what they did, because they were part of the Department of Justice or a Department of AttorneyGeneral. Many of them still are. 
In the federal area, I could see that that debate had progressed from the courts being administered by the Federal Attorney-General's Department to the sensible conclusion that the court should be given the responsibility for managing themselves and making the decisions about how to manage their operations, rather than be remotely administered by a department who had no real control over what needed to be done. So that happened with the Federal Court, the Family Court, and the Administrative Appeals Tribunal, on the model of the High Court. I think, subsequently, that was thought to be quite a successful change.

I have recently written a paper $^{3}$ about this, and the people who talk about that in that paper, the people who proposed it, said after a number of years, they thought the whole system was much more efficient. The courts were operating more effectively. Federally, that took away a lot of the previous tension that had existed between the judges and the people working in courts, and the Attorney-General's Department in relation to how the courts were administered.

KR: So can you tell us a little bit about that vision when you first arrived at the Federal Court?

WS: Very importantly, independence came with responsibility and accountability. So organisational responsibility was holistic. So everything we did as an organisation, put aside the fact that we were a court, needed to be done in organisational terms in the best possible way. Innovative leading. World leading. We had a saying within the court that we wanted to be and to be seen as a world-leading superior court. Which drove some of the strategies. That's one of the reasons why things like managing court records and managing the record and related issues was an important issue. It was part of the holistic approach to management of the organisation. So one of the things I focused on was managing organisational issues of the court. Not as a court, but as an organisation.

AG: I mean that's a massive shift for many, not just judges, but in the legal profession, to come to terms with. To think about courts organisationally, rather than only institutionally. You have been talking about the Federal Court being a national court, but also about how the court is perceived by the public and how the public can use it. Did you want, for the record, to describe some of those other innovations?

3 Warwick Soden, 'Self-Administration in the Federal Court of Australia' (Speech delivered at the JCA Colloquium, Noosa Heads, 10 October 2014). 
WS: Yes, and this is all really important background as to why we are now in the position we are, in a records sense. It's almost a consequential offshoot of what we've done in the past. Wishing to be perceived as, and to be, a world-leading superior court meant that there were many strategies that needed to be undertaken. That included all of the practice and procedure reforms; it included the buildings; but included important things like focusing on courteousness and politeness; cost reduction; time reduction; and also really important things like an appearance of modernity, rather than an appearance of being a colonial relic.

AG: There are major innovations that you've overseen too in terms of the individual docket system and e-filing and other things, which, again, most people in the general public wouldn't be aware of, but [which] are hugely innovative in terms of how people can access courts quickly.

WS: Yes, well, the reason that we now have a Records Disposal Authority and an electronic court file goes back to a whole lot of the related issues about being a modern, accountable, responsible institution, which happens to be a court. So if we're going to move to the modern environment and we're going to work in an environment that the business community expects us to work in, the clients of the practitioners, we had to take decisions that I persuaded the judges to take, about making assumptions about what it meant to move from the paper to the electronic environment. Because, importantly, the business-to-business interactions would be electronic and the legal profession would be expected by business to work in that environment. They would then expect us to work in that environment. So we would be perceived as being antiquated and out-of-date if we did not plan to do the same thing. So we developed what was called an e-services strategy. We needed to say we can do electronic filing, we can do electronic hearings, we can do things in the courtroom without paper. We were very careful, and I emphasised this, we needed to be careful that what we did electronically was what should be done, not what was done in the paper context. We did a fair bit of work on that, all of those types of initiatives as a court and as an organisation improving its performance ultimately led to in the e-services strategy, which was the creation of electronic work file, and all of the things that went with that. It was the creation of the electronic court file that drove the requirement to make a decision about what comprised the court record and what wasn't part of the court record. For the purpose of Lyn Nasir, getting a records authority for the digital record to be accepted by National Archives. You couldn't get the judges to focus on the record unless it was in the context of ...

KR: The modern court. 
WS: Exactly.

KR: That's very important. As a way back into how the court conceived of itself as managing an archive, there is actually an earlier question which comes back to your views around when you came in to be a manager of an organisation. That is, of course, a court is different to any other organisation in that it is constitutionally placed and has constitutional frameworks within which it operates.

WS: Yes, but one of the things that is misunderstood often is the constitutional position of the court in terms of judicial independence. Judicial independence is about judges. Not about the institution of the court. The best way of highlighting that fact is there was no issue of judicial independence when the courts were administered by the executive. Do you know what I mean?

KR: Yes.

WS: The transfer of responsibility to the court wasn't for judicial independence. It was for organisational performance reasons. So there's no such thing in the law as institutional independence of the court. There's only judicial independence of the person making decisions under Chapter III.

KR: So the follow-up question then to you, Warwick, is why do you think the court was excluded from the Archives Act? ${ }^{4}$ Because if you follow that train of thought, the court should not have been excluded from the Archives Act, should it?

WS: I think the only reason that comes to my mind is the court of record issue that we touched on before: a superior court being a court of record. Now that's got nothing to do with judicial independence or ... the independence of institution. Superior courts of record.

AG: It is a common law question.

WS: And if it's a superior court of record. All Supreme Courts, Federal Courts, are courts of record. There's common law requirements on what the record of that court should be. Nothing to do with judicial independence. 
KR: No, but it is interesting, I think. It's really interesting because, theoretically, it could have been clearer. The National Archives could have been clearer about the things that were not subject to the Archives Act, as opposed to the entire court not being subject.

WS: Yes, look, I don't know what was considered at that time. But you know, there are issues in relation to the perception of judicial independence that sometimes blur decisions about what it is and what it isn't; it's certainly not about prerequisites of office.

KR: No, but by virtue of the fact that the court was exempt, we're interested to know how the court saw itself in terms of its management of its archive.

WS: The court, being exempt, didn't change its common law requirement to be a court of record.

AG: No, not at all. But that's the fascinating conundrum, I suppose.

WS: It is muddied, yes, and I think maybe that's behind the reason why the court was excluded from the Archives Act. But I'd like to say that we take our historical archival responsibility seriously. Even though there's no statutory requirement to do so.

KR: That's what we're interested in: how that evolved. So part of it is the modern story that you're telling us. That, by wanting to be the sort of court that it is, that's the obvious consequence; that you want to be in the spirit of the Archives Act. But what else, I guess organisationally, lead to that?

WS: Well, I think it comes from two sources. One is that the sense of having an archival responsibility comes from the tradition of being a court of record, if I could describe it that way, which goes back to colonial times. There is archival relevance in the court of record information. That's one issue. On the other side of the coin is the, I think, accepted responsibility from Michael Black, other Chief Justices. And those of us in present charge of maintaining the historical record of the institution, which is an important institution for the country, dealing with some of the most important cases affecting civil society and the commerce of the institution-commerce of the country, which would be important for the future and for the history of the country. One of the things I'd never looked at closely here, and we didn't do it in the Supreme Court, was do a survey of who was asking for what and for what purpose. But I know that in the Supreme Court, before you had any electronic information, you maintained manual indexes of plaintiff-defendant or applicant. I think many organisations, law firms, financial institutions did due-diligence 
work in relation to whether there was anything in the indexes in respect of someone being sued for what. Now, all that can be done electronically these days.

KR: So that probably takes us nicely back to, if you can, charting for us the relationship between the court and National Archives. Given that it wasn't a strictly ...

WS: Harmonious.

KR: ... formal one.

[Laughter]

KR: How that evolved, really, to the extent you know from the start and then how it changed.

WS: Well, I had nothing to do with them really.

Lyn Nasir (LN): Well I suppose when I came in, the ...

KR: When did you start then?

LN: I started in late 2007.

WS: There was a person before you.

LN: There were several before me, but getting a records authority had been going on for many years. I think we stopped with our other records authorities the year 2000. The National Archive said, 'we're not taking anything from you anymore; you've got to revise that and come up with something new'. It was called DIRKS [Designing and Implementing Recordkeeping Systems]. There was apparently lots of interviews with the Deputy Registrar at the time and ...

AG: Can I just pause there? So DIRKS, just so we can clarify, is not just for the court. Looking at the materials we've been looking at, the National Archives itself was having a recalibration of its relationship with ...

LN: All agencies.

AG: ... and how they define what an agency is and, therefore, also what they keep and select, and to rethink those sentencing of records questions. So I suppose what's really interesting to us is that we know that in 1994, there was a record disposal authority with NAA?

LN: Yes, there were several. We sent everything then. All our court files went to National Archives. 
WS: Everything went there and they kept the lot.

KR: So there was no decision-making at all? It was just everything went?

LN: Yes, all paper went. We still sent everything. They considered everything from the court as significant at that point.

AG: So that period between 1976 and 1994, it's very hard to ascertain what happened.

WS: They were getting miles and miles of storage cost.

LN: They couldn't take a thing anymore so that was it. Economics probably drove a lot of that.

WS: I know I gave it a fleeting thought in the early days and was just very relaxed that everything was going off to National Archives and being kept. I didn't have to worry.

LN: Everything was retrieved from there too. We'd get files back. They'd go back and forth, back and forth. It was all working pretty well. You know what? We would have been under the Attorney-General's disposal authorities.

WS: At that stage.

LN: That's why our Records Disposal Authorities are dated a bit late. They're in the early '90s I'm pretty sure. Yes.

WS: I would have thought the Attorney-General's Department at the time would have said, 'off to archives'.

LN: They wouldn't have been able to send it without some authority. So there would have been something somewhere like a class number or whatever. You can't send them anything unless they know all that. A lot of them are handwritten. I've scanned them. They're handwritten files that we've sent off. Sometimes, they don't even match up with this versus that. How useful is this, I mean research-wise?

AG: Hugely. Because that's the story. That becomes the question, I think.

KR: They're part of the things that I think will be part of a protocol as to what would be important for future researchers. In a way, this is amplifying this function between a court of record and a ...

WS: And an archive. 
KR: ... that houses documents that are of national significance. In a way, it's the beautiful distinction you're making between the judges, as independent and as judges, and the court as an institution in a modern democratic Australia. I mean the way you've articulated that is so helpful for showing how this plays out in terms of the nature of history in a modern postcolonial society.

AG: And I think we're now at a point, because of the innovations and the commitment of you and others in this court, and how this court has imagined itself into being, that the record and file have become electronic, so it's a whole other question about how you store metadata and access the metadata.

WS: There was a confluence of records authority requirements, and an electronic record. It came together. That was what I would describe as a break point in defining the court record, and focusing on the requirement to identify important files for archive purposes, separately from the courtroom-what can be classified as 'significant files'. I must say, I didn't focus on that path when I came here. I was only focusing ...

AG: You're building a court, right? It's a different thing.

WS: [Laughs].

KR: I'm going to put that in at terms of your vision. Your vision was forward looking.

WS: It was. It was. It was. It was.

KR: Which, therefore, in and of itself means that archives are not within your frame, and I don't mean that in a judgmental sense.

WS: No, I can say I did not think of the future archive requirements at that time because everything was being kept.

LN: Yes, that's true and it was being taken care of then.

WS: It was not an issue that needed to be managed and it was not a cost issue for them.

AG: So to return to this question of significance, which is really an internal issue for the court, a response to DIRKS it's ...

WS: Developing.

LN: Yes, and that's in the records authority. We have to define what we think is significant. We still haven't defined it completely. 
WS: It's not finished.

LN: Yes. The conversation that went around that was National Archives coming back to us and saying, 'We can't take everything'. And we're coming back to them and saying, 'But you should take something. We feel that there are some cases that we have here that really should be sent'. They're coming back to us and saying, 'Yes, we agree with that. We've got to put a percentage on it. We can't give you ...'. That's where the 10 per cent of files came in. They were negotiations really with Imelda Payne, Director of Information Services at the time, and myself, just trying to flesh that out. Also, with Warwick's backing, and the Deputy Registrar at the time saying 'well, we do need to send-we know we have to send-something. We feel it should be on a public record in a national research area, which is the National Archives, that these significant files are kept. Even though you don't want everything, you should have some'.

WS: Significant could be a number of different things. I've expressed some views. There are some variations. Significant files, to me, ought to be a representation of what the workload was, not just the important cases. So when we were thinking about the 10 per cent, should that be a random collection of 10 per cent of the files of a year? Should it be a request for an identification of the significant cases from the judges and then a top-up to make the 10 per cent by a random collection of everything else? So that's out there for consideration at the moment.

I think what is significant to me is much more than just the big and important cases. Because cases that have commenced, been worked up, case managed and settled don't have the big judgment, don't have the big hearing.

AG: No, they don't.

KR: Then what about the court's own internal administration? How do you conceive of that in your archival decision-making?

WS: We don't. [Laughs].

KR: I mean it's again, back to you, that distinction. You are an organisation.

LN: Well, no, we keep the judge's minutes. They will all be going there; significant. But as you say, that's probably out of the administration because that's the judicial side of things. Our rules and practices, yes, they're kept.

WS: Practice committee papers and real committee papers, yes. 
LN: They're kept but they're kept with us. We have the obligation to keep that. Nothing goes off to National Archives. The only thing going to National Archives are our significant cases and our native title files. That's all they've been taking out.

KR: I mean but this is really pre-empting a later output of the project, which I haven't made, but I think the focus of our research is highlighting the significance of the court as an institution. As an organisation. It's almost your job in a way and the way you conceived it is that that's a significant part of this institution that arguably is significant for the archive for further down the track.

WS: It should be actually. It should be.

AG: Well, it's extraordinary to us that we were the first people who have ever asked and got access in National Archives to looking at those documents that discuss the setting up of this court.

LN: We're not that old yet really. [Laughs].

AG: It's kind of part of broader projects for us about what it means to take your own Australian innovations in jurisprudence seriously.

WS: Most of the other courts-most, I think it's fair to say, you've probably already experienced this-but most of the other courts of Australia that are still connected in institutional terms with the executive aspire to be like us.

KR: That's right. I guess their records would be done through the Justice ...

WS: Department of Justice.

KR: Yes, and the requirements of those departments.

AG: That's right.

KR: They would, you would hope, have approached looking at their own management as part of the archive. Because I think for our project, the outcome is to think of the court beyond the cases that it hears. Sure, it's set up for the cases that it hears and those become significant, but it's the organisation as well.

LN: It's a lot of other things as well.

WS: It's the institution, in all aspects.

KR: Exactly, that is significant and significant to the development of Australian identity. 
LN: These days, we are really trying to maintain the electronic side of administration up to speed too. What we're trying to do is keep everything electronic. It's hard because a lot of it is emails now.

AG: I mean it's a question facing people [who are] thinking not just in terms of courts and histories and legal history projects but all sorts of historical things, like just writing biographies in the future where you can't read anyone's letters. Because it's now electronic.

We were talking about what is significant. Back to the significance problem. So I was just saying to Lyn: I had a look at the current Records Disposal Authority just in preparation, again, for coming today. When you're reading that, you're thinking, 'well that's perfectly sensible'.

KR: Yes, for this record, let's read out what constitutes part A and part B of the court file according to the Records Disposal Authority.

WS: Well, part A is the words that define what is essentially the court record. The document that commences the proceeding that identifies the parties and the cause of actions, together with the orders made at the end of the proceedings, comprises the court record. But to be clear about that, you've got to add things like amended pleadings, et cetera, et cetera. Because there might be a change to the parties. But importantly, what the court record doesn't include - the official court record—is the reasons for the decision ...

AG: Unless they're published.

WS: Yeah, but a lot of reasons aren't published. Or the transcript, the description of the parties; who sued what for whom, and the orders made and variations in appeals and first in matters, et cetera, et cetera. In order to get that, sometimes you might have to have a look at interlocutory decisions in relation to either adding or deleting parties. So the case that's commenced may not be the case that has all the parties at the end.

AG: So I'm gathering no judge would have had any dispute with part A at all?

WS: No. No.

KR: Because that's the law.

AG: So part B: what was the nature of the debates about what was going to be in part $B$ ? 
WS: No, there were discussions at the meetings about whether or not reasons for judgments or transcripts should be included. Because I can remember one of the judges saying, 'But the High Court has a transcript in all its cases, why shouldn't we?'. Well, the answer to that is because we don't need to in many of the cases.

AG: But that's also interesting because the High Court can't be appealed from. So the notion of what is on their record has completely different significance.

WS: The judges could see the sense of having an electronic court file system that automatically categorised part A and part B.

AG: About part B, was there any debate? The conceptual thinking about what to preserve, what might be of future value? This is the Apple and Samsung issue.

WS: I can tell you: no, there wasn't. The reason was this: once they were satisfied that part A was defined and it was going to be kept, everything else was part B.

KR: So you keep everything.

AG: Or nothing.

LN: Well we only have to keep part A forever.

WS: Part A was the record. Part B was everything else, and in the context of significant files being kept, that was going to be $\mathrm{A}$ and $\mathrm{B}$.

AG: Right. So back to the circular question about significant files and how to decide ...

KR: ... what was significant.

WS: They really left ... They've left that to us.

KR: The process is still an evolving one, you think?

WS: We're still having discussions about what it ought to be.

LN: We're starting prepared cases to go now. There's two massive ones in the ACT [Australian Capital Territory] that we know are going to be and so we're preparing them to go. But what we've got to do is have an access policy, which we're still working on as well. 
KR: So this is where I hope our work can be practically significant too, because there are quite interesting process questions about how those decisions are made. In the sense of, I mean even our discussion today, at the moment, you're only thinking about the cases that are significant as opposed to the other documentation that exists in the Federal Court that should be, perhaps, in our view, be reflected upon to be identified as significant.

WS: That's fair comment.

KR: I was saying a bit earlier to Lyn, when I first got involved and interested in archives from being a legal academic, it was in the context of not courts but the Department of Immigration and which documents it kept from my work on citizenship. Being amazed at things that were about to be sent and destroyed that were of real national significance. I have a memory, and I need to follow this up, that committees were established where there were historians. Or people not from the actual organisation who were involved in that process of making decisions about significance.

One thing I'm just literally throwing up, that's coming to my mind in this discussion, is whether the Federal Court, in its thinking about making those decisions about significance, should be thinking about external people who could be on the committee to assist in that process.

WS: I think we should think about it.

AG: Well, I think that's how ... I mean just about the part A and part B. Because all lawyers will understand that but the historiographical problems of thinking about how we interpret what we save, keep and curate and then how you access it and what you might think is of value and what kinds of stories or histories are able to be told. Most lawyers find that very difficult to understand. Now, Chief Justice Allsop, I've had one conversation with him about this project, when we asked for permission to come and work, and he gets it implicitly. He gave me an example from his own experience about how he had thought about that. So, as an institution, the fact that ...

KR: You're doing all this stuff.

WS: It's important. It's important. It's important, yeah.

AG: The access question is a really difficult one that sort of exercised us a fair bit because, and again this goes to the native title question, because clearly how to modernise and become a national court occurred at the same time as the introduction of the native title jurisdiction. 
LN: Ian Irving [Former Native Title Registrar of the Federal Court of Australia] was working on that and we've got a MoU [Memorandum of Understanding] ready drafted. It's a draft. It's going to the judges. The native title judges. It is ready for final sign off. Because we are wanting to send away native title files and National Archives, in their wisdom, and it's from a practical thing, and they're saying, 'Well, why should we accept all of them if they're not going to be accessible? We're not a storage area anymore'.

AG: See, this is fascinating.

LN: We are here for significant files to be placed with us so people can access. So if you're not going to give an access policy, thank you very much, we don't want your files. We know we've got to take them but they're putting the onus back on us.

WS: That's fair enough. I think that's fair enough.

LN: We're nearly there because Ian has got something pretty good. The only thing that's not worked out is the expert reports, but anyway.

AG: It was really interesting before to me and I think this is a really exemplary thing about this court, is when you were thinking about what native title meant when it arrived jurisdictionally. To be able to think okay, this is a majorly ground-shifting political and historical moment in the history of this country. Like post-Mabo, everything is different.

WS: It is. It is.

AG: Everything is different. In how we think about what institutions do, who accesses, all of that has to be fundamentally different. The fact that this court both could have the foresight and imagination to say 'we need to think of practice guidelines that include things that don't ordinarily look like law but are law' and, at the same time, going 'we've got to treat these matters exactly the same as we treat all other matters, with efficiency'. That, I suppose, is a really important thing to consider. If we think about how native title matters are to be archived and access[ed], that gives an indication, I think, of how everything else should be.

LN: We've actually spelled a lot of that out. All [those] diaries and sound recordings, we've actually ...

WS: It's true. I mean you've got to apply both sensible practices to that issue.

AG: Yeah, because the nature of what it is to be a court fundamentally incorporates all of that. 
WS: Yes.

AG: That's, I think, a really important thing to consider-how to think about access for native titles matters and native title materials, which are diverse and this complexity of not everything can be electronically managed.

LN: Well that's it. You want to do that in the electronic world, it's going to be difficult, isn't it?

WS: Yes, I know, and there has to be some sort of sensible consideration given because these things that are presently thought to be quite sensitive are not going to be sensitive in 50 years', 100 years', 200 years' time. They're going to be critically important.

AG: Yeah, so and I suppose the debates for Indigenous communities about ownership and repatriation and having some of those conversations with colleagues, researchers, who work in that area, but you've got to understand the responsibility to hold material because it's a superior court of record and what it means to preserve things and who and how that is accessed.

KR: It's not dissimilar to concepts that go with things like cabinet documents that are closed for particular periods of time because of the sensitivities ...

WS: Yes, true. True.

KR: ... where there is a need for closure because of other interests and how you work out what that period will be in light of the interests that are involved.

WS: Yes, I think there's some common sense being applied to that. But the judges are going to have to be satisfied that there's something in place to protect some sensitivities of litigation in the present time.

KR: But also what would be interesting, coming back to that external advisor, how much the Indigenous communities are consulted on those sorts of questions.

LN: Well Ian is definitely talking to them about expert reports.

WS: Yes, they have. They have been.

LN: I think any confidential order that's been put now ... Because we're sending a file with a page on the front that will summarise what can and can't be accessed in that file. They're going to be putting the details of 
any confidentiality orders so that National Archives still have the right to come back and ask about that. But it seems-I wanted to clarify that with them-but it seems like they're asking National Archives to do that. They're giving them contact details so that if they feel ... they can contact the Indigenous body direct.

AG: But, I mean, it's the community, not the individual that sort of is the point. Those things are going to be ongoing relationships. So, I suppose it's an interesting difficulty ... what are obligations of courts ... to multiple publics [different groups, and communities]? I mean I have used collections [of different community organisations] at Mitchell [Library] and other places, some of which [are restricted and require permission from the group], some ... that I can copy. [Court records, however,] are not of the nature of those kinds of records. I think the difficulty [for courts in making access rules] is going to be about who the parties are ... a problem that has beleaguered the native title jurisdiction. It is going to be those same kinds of issues, in terms of consultation about who can then access materials.

LN: Isn't there a move too, Warwick, for the judges now to put a limit on orders? You know there's going to be a time when they can be lifted.

WS: Yes.

\section{[Over speaking]}

LN: Because at the moment, there's no end date. That's the difficulty with anything like this: no end date. So I think there was a move to see if she could put something in place. Okay, we'll put this on but there is an end date or a review date or something, so it doesn't go on forever.

KR: Yes, like a sunset clause.

LN: Yes, and that's our problem. Because these things have got to be around forever.

AG: Because also, just for non-native title matters as well, when does a file become closed? You know, to make the decision about when things are sent. I mean, you say you're preparing things now to send. So the idea that this ... clearly you can't be sending significant matters until they've been ...

KR: Concluded.

LN: Well, these are about 2003, these ones we're looking at now. So that's quite a ... 
AG: Yes, so the lag itself obviously is part of the protocol that you have to $\ldots$

LN: Well, hopefully there won't be that real lag later. We will probably get all of those. Those big ones like that, we'll identify them. But then we're looking at significant files like 12, 24 months after the event really, aren't we? We're flagging them.

WS: Yeah, we're not going to do it until the prospect of the appeal period having been passed. Because on the list of documents, I mean, if you're just looking at our file, parties and orders, there might subsequently be a Full Court, a High Court appeal that reverses the decision.

AG: Exactly.

WS: That's noted on the original file. So you want the benefit of all that on the original file.

AG: Can I just come back to this thing about selection by number. You know, by ... because obviously, this is something that a colleague of mine who works very closely as a $19^{\text {th }}$ historian with Supreme Courts, in particular in Victoria, said they did a similar thing. But they didn't even think about what they were keeping. They just went, 'we're just going to keep ...'. They just literally looked at what was there.

WS: No, I wasn't prepared to let that happen.

AG: I think you need to have that kind of sweep. Because we don't know. We want to know, you know, you're looking at social histories of who the parties are. What the legal issue is has become sort of ...

KR: Who had access to the courts? What's in the nature of the submissions? Who were the lawyers? How do we think about those?

LN: We always had that in mind that we would be looking at a selection of the cases we look at every year. So there's a cross-section of ... We deal with migration-they mightn't be significant migration-but we deal with migration so we want a sample of all the things that we do. So that was always a category that we were going to look at.

AG: That's back to the idea of the history of this organisation, also lets you see that.

LN: Yes. Exactly. That's important. 
WS: I think the history of the organisation is going to be in a lot of the documents and records we have in the administration files. The committee meetings, I mean; you would have seen that.

LN: We've got a scanning project going on at the moment with just doing that. All the background papers to the judge's meetings, which are where all the work happens.

WS: The introduction of the electronic court file and the fact that we'll be able to keep, in the future, the record electronically and transfer significant files electronically is the solution to the future cost problems of keeping records.

As discussed in the introduction to this extract, the various issues raised in this interview are of continuing relevance to the court and involve ongoing projects. This interview was conducted on the eve of the court's $40^{\text {th }}$ anniversary as a national institution and captures the respective participants' thinking at that time. At the time of publication, the court had not finalised its significant court file policy, although progress has been made in developing a policy on accessing native title files, which will have an influence on other accessibility policies, including the court's significant files. 
This text is taken from The Court as Archive, edited by Ann Genovese, Trish Luker and Kim Rubenstein, published 2019 by ANU Press, The Australian National University, Canberra, Australia. 